\title{
Assessment of the Level of Digitalization of the Economy and Society in Russia
}

\author{
Dmitrieva E. \\ Department of Management and Innovation \\ Moscow State University of Civil Engineering, MGSU \\ Moscow, Russia \\ k_dim73@mail.ru
}

\begin{abstract}
The subject of the paper is to study the development level of digitalization of the economy and society in Russia. The aim of the study is to review the available statistics in order to quantify the development level of digitalization of the economy and society of the country and determine its position in the international rating. To analyze the digitalization level of the economy, statistical information and methods of analysis, comparison and expert estimates were used. A comparative analysis conducted in the study made it possible to propose a comprehensive methodology for calculating the composite Digital Economy Development Index (DEDI) based on a wide range of available indicators. It also allowed grouping individual countries according to their level of development. According to the results of the study, it should be concluded that in Russia, as well as in some European countries, the development of digitalization of the economy and society is happening at a comparable pace.
\end{abstract}

Keywords - digital economy; digital technologies; digitalization; integrated indexes

\section{INTRODUCTION}

The main feature of modern society is the active penetration of digital technologies into human life, which is due to progress in the fields of information technology and telecommunications.

In the context of digital globalization, the processes of production, distribution, exchange and consumption of information become central in comparison with other types of economic activity, strengthening the digitalization of the economy. As a result, a new system of organization of economic relations is being formed - the global digital economy with its own laws and development trends.

As foreign studies show that many countries pay considerable attention to the formation of a digital society, which is confirmed by the adopted strategies/programs for the development of the digital economy, including $[9,17,18]$ :

1) Germany is a pioneer of industrial technology, the birthplace of the Industry 4.0 term. Here, about $10 \%$ of the population is employed in high-tech industries, which is about two times more than in Russia. For Germany, the central role of the state in financing promising digital projects is uncharacteristic, the state sees its main function in creating the rules of the game, developing fundamental education, stimulating research;
2) South Korea and Japan managed to create the largest digital companies, where innovation mainly occur, on the basis of traditional corporations (Samsung, LG, Toyota, Sony, Toshiba, SoftBank). The ecosystem of startups is less developed here, although there are some successful projects, for example, in the field of Internet commerce and ecosystems (Rakuten), and in the field of the creation of Internet messengers (Line, Kakao);

3) China, where the share of the digital economy is comparable to the United States, despite the fact that it belongs to developing countries, has been successful both in identifying and implementing promising digital solutions, and in developing its own export-oriented projects (Alibaba, Huawei);

4) The United Kingdom is one of the most digitally developed countries in Europe and the world. The British government identifies a number of promising technologies that it considers strategically important for the development of the economy and announces its intention to become a leader in these areas, highlighting the blockchain and $5 \mathrm{G}$ connection. The development of communication systems in the UK is very successful - as early as $2018,98 \%$ of the country's territory was covered with $4 \mathrm{G}$ connection, while in Russia, where connection is also well developed, $4 \mathrm{G}$ is available only in medium and large cities.

However, studies conducted by various international analytical companies (McKinsey, World Economic Forum, Boston Consulting Group) show that today Russia is not among the leaders in the development of the digital economy in many generally accepted indicators, and that the share of the digital economy in Russia's GDP is 2-3 times lower than that of more developed economic countries.

Thus, it is obvious that the problem of the formation and development of the digitalization of the economy and society in Russia is significant and relevant both for the scientific community in order to develop comprehensive studies on this topic, and in practice for the full formation of the digital economy in order to increase Russia's competitiveness at the global level.

\section{MATERIALS AND METHODS}

Given the increasing number of economic activities made available by digital technology and their growing economic importance, assessing the digital economy is a priority. In this 
regard, using methods of analysis, comparison and expert assessments, we will conduct a comparative analysis of numerous integral indices that measure the level of development of the digital economy in individual countries.

The degree of the impact of digitalization on national economic and social life determines the place of each country in the world community. To assess the degree of digitalization coverage of any country, indicators are used that indirectly or directly assess it.

Indicators that indirectly assess digitalization as a trend include, for example, the Networked Readiness Index (NRI) and the Global Innovation Index (GII).

The Networked Readiness Index (NRI) is a comprehensive indicator that characterizes the level of development of information and communication technologies (ICT) in different countries of the world. It is used for an indirect assessment of the digitalization trend because ICTs play a leading role in the development of innovations, increasing labor productivity and competitiveness. And since the majority of new ICTs are based on digitalization, this means that this index implicitly reflects the penetration of digitalization in all spheres of public life.

The annual results of the calculation of this index are presented to the World Economic Forum as part of "The Global Information Technology Report" [9]. The NRI measures the level of ICT development in a particular country according to 53 parameters divided into 3 groups: the availability of conditions for the development of ICT; readiness of citizens, business and the state to use ICT; level of ICT use in the public, commercial and state sectors.

In accordance with the value of NRI for 2016, Russia ranked 41 st in the ranking of 143 countries, lagging behind the top ten countries (Singapore, Finland, Sweden, Norway, the USA, the Netherlands, Switzerland, Great Britain, Luxembourg, and Japan).

The second indicator used to assess digitalization is the Global Innovation Index (GII), which characterizes the country's innovative activity potential and its result, calculated as the average of two sub-indices:

1) a sub-index of innovation costs, which allows assessing the elements of the national economy in which innovation processes take place, divided into five main groups: (1) institutions; (2) human capital and research; (3) infrastructure; (4) the level of market development; and (5) the level of business development;

2) a sub-index of innovative results, which reflects the actual results of such efforts, divided into two main groups: (6) results in the field of knowledge and technology and (7) results of creative activity.

So, according to the value of GII in 2017, Russia was on the 45 th place [3].

Since digitalization is becoming a universally recognized global trend in the development of the economy and society, there is a need for a more accurate and directed assessment of the impact of this trend on the economy and society of different countries. The indicators that directly assess the impact of digitalization on national economic and social life include those that meet the following requirements: taking into account the coverage of all areas of public life - business, science, the social side and the ordinary life of citizens, and also the effective use of the results available not only for specialists but also for ordinary citizens who have the skills to work with this information.

The indicator of assessing the degree of digitalization coverage as the trend of the global development of the economy and society is the I-DESI (International Digital Economy and Society Index), which takes into account 5 main groups of indicators: telecommunications, human capital, use of the Internet, digital technology integration, digital state services. At the end of 2016, Russia took 39th place, ahead of China, Turkey, Brazil, and Mexico with its index value of 0.48 . The most advanced countries in terms of digitalization in the European Union in 2016 included Denmark, Finland, Great Britain, and Sweden with an index value of 0.76-0.72 [3].

Along with this index, there is the ICT Development Index (IDI), which is an integral indicator that includes 11 indicators that characterize access to ICT, the use of ICT and practical skills in the field of ICT. In the ranking of 2017, Russia fell to 45 th place in terms of ICT development. The rating is annually compiled by the International Telecommunication Union (ITU), and Russia was on the 43rd place in 2016 [5].

International comparisons on the totality of factors demonstrate the promising positions of Russia in key indicators of the development and implementation of digital technologies. So, according to the rating of the World Economic Forum, in 2018, Russia ranked 43rd among 140 countries, including 25th place in the "Development of Information and Communication Technologies" area, which is primarily provided due to a significant share of mobile phone users among the population and the widespread use of fiber optic Internet [6].

Russia is consistently ranked in the top 50 of all major international digital development rankings. However, in 2012 2016, Russia's positions in a number of them have declined: in the electronic government development index (EGDI) - from 27 th to 35 th place, ICT development index (IDI) - from 41st to 45 th. At the same time, Russia took 11th place in the global cybersecurity index (GCI) in 2017.

In this context, the "Digital Russia: New Reality" study conducted by McKinsey consulting company, the results of which were published in July 2017, is of interest. According to the study, digitalization of the economy will increase Russia's GDP by $4.1-8.9$ trillion rubles by 2025 , which will be from 19 to $34 \%$ of the total expected growth. An optimistic economic forecast is based on the results of introducing fundamentally new, breakthrough business models and technologies, which include digital platforms, digital ecosystems, analysis of large data arrays, Industry 4.0 technologies, etc.

At the same time, the study notes that Russia is not yet one of the leaders in the development of the digital economy in such indicators as the digitalization level, the share of the digital economy in GDP, the average delay in the development 
of technologies, etc. The share of the digital economy in Russia's GDP is $3.9 \%$ (according to Boston Consulting Group - $2 \%$ ), which is 2-3 times lower than that of the leading countries, and the volume of digital technology exports is 4 times less than imports. In addition, the digital inequality of the regions persists (only $4.2 \%$ of feldsher's posts in the village are connected to the Internet).

According to researchers from McKinsey, in order to 3 times increase the volume of the digital economy in Russia from 3.2 trillion rubles in 2015 up to 9.6 trillion rubles in 2025 , it is necessary to maintain its average annual growth rate of $12 \%$, which was observed during the period of 2010-2015. This is equivalent to an increase in the share of the digital economy to 8-10\% of GDP (taking into account the dependence on oil prices and other macroeconomic indicators), which corresponds to the current level of the countries leading in the volume of the digital economy: the USA, China and Western Europe [3].

\section{RESULTS}

A significant drawback of the above assessment of the digitalization level of the economy and society of various countries, including Russia, in international rankings is the limited scope of their research with formal indicators, which are mainly related to the assessment of the informatization level (the number of computers, telephones, Internet connectivity, economic effect, etc.). Also, when assessing the digitalization level of different countries, attention is mainly paid to the technical side and the development of the digital economy, and the level of ICT infrastructure is identified. All this leads to the fact that the country takes a low place in the rating because it was not able to fully provide the data necessary for the calculations, since statistics on them (in accordance with national legislation) are not kept.

To eliminate this problem, the author proposes a comprehensive methodology for calculating the composite Digital Economy Development Index (DEDI), which involves considering the development of the digital economy based on a wide range of available indicators that allow an objective assessment of the five sub-indices through which the DEDI is graded. In turn, sub-indexes are assessed through specific indicators, the information on which was taken from the Digital Economy: 2019 statistical digest compiled by the research group of the National Research University Higher School of Economics (Table I).

For a possible comparison of the indicators of variables that are expressed in different units of measurement, the data normalization method is used. Each of the variables is converted into points on a scale from 0 to 1 , where 1 is the value for the maximum variable (the higher the point, the higher the level of "digital development"), using linear transformation:

$$
y(x)=\frac{x_{i}-x_{\min }}{x_{\max }-x_{\min }}
$$

where $x_{i}-$ the value of the $i$-th specific indicator; $x_{\operatorname{mix}}-$ the minimum value of the specific indicator; $x_{\max }-$ the maximum value of the specific indicator.
TABLE I. THE PROPOSED SYSTEM OF SPECIFIC INDICATORS CHARACTERIZING THE LEVEL OF DEVELOPMENT OF THE DIGITALIZATION OF THE COUNTRY'S ECONOMY AND SOCIETY

\begin{tabular}{|l|l|}
\hline \multicolumn{1}{|c|}{ Sub-Index Name } & \multicolumn{1}{c|}{ Specific Indicator } \\
\hline the population of & $\begin{array}{l}\text { Internet access in households by country } \\
\text { Use of mobile devices by the population to } \\
\text { access the Internet outside the home or work } \\
\text { by country } \\
\text { Digital skills of the population by country } \\
\text { Using the Internet by the population to order } \\
\text { goods and services by country }\end{array}$ \\
\hline $\begin{array}{l}\text { 2. Digital } \\
\text { infrastructure } \\
\text { development and }\end{array}$ & $\begin{array}{l}\text { Fixed broadband Internet subscribers by } \\
\text { country ICT } \\
\text { Broadband subscribers by country } \\
\text { Fixed broadband internet subscribers by } \\
\text { connection technology and country } \\
\text { Active subscribers of mobile radio telephone } \\
\text { system by country }\end{array}$ \\
\hline $\begin{array}{l}\text { 3. Higher education } \\
\text { and training of } \\
\text { personnel }\end{array}$ & $\begin{array}{l}\text { Share of ICT specialists of the highest level of } \\
\text { qualification in the total number of employees } \\
\text { by country } \\
\text { ICT specialists by qualification level and } \\
\text { country } \\
\text { ICT specialists under 35 years of age by } \\
\text { country }\end{array}$ \\
\hline $\begin{array}{l}\text { Broadband Internet access in organizations by } \\
\text { country } \\
\text { Intensity of using digital technologies in } \\
\text { organizations by country } \\
\text { Using CRM-, ERP-systems in organizations by } \\
\text { country } \\
\text { Electronic procurement, sales in organizations } \\
\text { by country }\end{array}$ \\
\hline $\begin{array}{l}\text { Share of the ICT sector in the number of } \\
\text { employed in the business sector by country } \\
\text { Share of the ICT sector in the gross value } \\
\text { added of the business sector by country } \\
\text { ICT sector gross value added structure by } \\
\text { economic activity and country } \\
\text { Export of ICT-related services by country }\end{array}$ \\
\hline
\end{tabular}
used:

To calculate the sub-index (SI), the following formula is

$$
S I=\sum_{i=1}^{n} \frac{y_{i}}{n},
$$

where $y_{i}$ - the normalized value of the $i$-th specific indicator; $i$ - the order number of the specific indicator; $n-$ the number of specific indicators.

After that, the author assigns weight coefficients $\left(w_{j}\right)$ to each of the five sub-indexes, based on which the general index is calculated.

Table II shows the values of weight coefficients of the above sub-indexes.

TABLE II. THE VALUES OF WEIGHT COEFFICIENTS OF THE SUB-INDEXES

\begin{tabular}{|c|l|c|}
\hline No. & \multicolumn{1}{|c|}{ Sub-Index Name } & $\begin{array}{c}\text { Weight Coefficient of } \\
\text { the Sub-Index }\end{array}$ \\
\hline 1 & Digitalization of the population & 0.15 \\
\hline 2 & $\begin{array}{l}\text { Digital infrastructure development and } \\
\text { access to ICT }\end{array}$ & 0.25 \\
\hline 3 & Higher education and training of personnel & 0.3 \\
\hline 4 & Business digitalization & 0.2 \\
\hline 5 & Impact of the ICT sector on the economy & 0.1 \\
\hline
\end{tabular}


The weight coefficients are determined by the following criteria:

1) the maximum weight (0.3) is adopted for the sub-index (factor), which has a maximum effect on the value of DEDI, i.e. for the sub-index "Higher education and training of personnel", due to the high requirements for human capital involved in the digitalization process and the inability to create, implement and use elements of a digital economy without the availability of appropriate personnel. The development of this sub-index (factor) is a key condition for the success of digitalization;

2 ) the second most important value $(0.25)$ is adopted for the sub-index (factor) "Digital infrastructure development and access to ICT", the third (0.2) - "Business digitalization". This is due to the fact that it is with the help of these factors that trained personnel will be able to implement digitalization plans. At the same time, the information infrastructure is the basis for the formation of a new business model that allows companies to be competitive in the development of the digital economy;

3 ) the sub-index (factor) characterizing the digitalization of the population is assigned to a separate group, since it demonstrates the ability and activity of citizens to use IT technologies to create comfortable conditions for their life activities, including the fulfillment of the two factors described above, with a weight of 0.15 .

4) the last group "Impact of the ICT sector on the economy" with a weight of 0.1 reflects the current result of digitalization based on the analysis of information from open sources.

To obtain a final generalized assessment of the level of development of the digitalization of the country's economy and society, the DEDI index is calculated according to the following formula:

$$
\text { DEDI }=\sum_{j=1}^{5} S I_{j} w_{j},
$$

where $S I_{j}-j$-th sub-index value; $w_{j}$ - the weight coefficient of the $i$-th sub-index; $j$ - the order number of the sub-index.

In accordance with the obtained values of sub-indexes, a rating is assigned that indicates the country's place among other states in this area. The country's aggregate rating is determined using formula (3) by calculating the weighted average of the sub-indices, each of which determines the quality of digital development in its own area. The advantages of the proposed methodology are the use of accessible and unified information that makes it possible to objectively make cross-country comparisons, the relative simplicity of calculations, and the ability to identify strengths and weaknesses in each area of the digital transformation of the country's economy.

Table III shows the countries according to the DEDI index, which were classified according to the level of development of the digital economy into four groups: 1) high level of development (DEDI $\geq 0.7$ ), actively developing $(0.5 \leq$ DEDI $<0.7)$, average level of development $(0.3 \leq$ DEDI $<0.5)$, low level of development (DEDI <0.3).
TABLE III. GROUPING OF INDIVIDUAL COUNTRIES BY THE DIGITAL ECONOMY DEVELOPMENT INDEX FOR 2017

\begin{tabular}{|c|c|c|c|c|c|c|}
\hline Country & 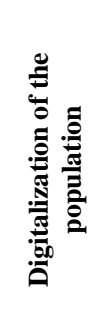 & 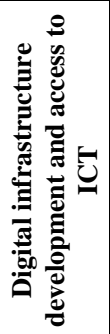 & 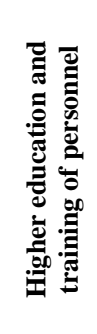 & 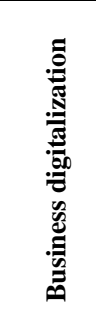 & 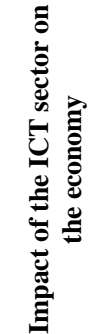 & DEDI \\
\hline \multicolumn{7}{|c|}{ High level of development } \\
\hline Sweden & 0.8455 & 0.9534 & 0.7264 & 0.9318 & 0.8213 & 0.8557 \\
\hline Finland & 0.6716 & 0.9048 & 0.6734 & 0.9946 & 0.8957 & 0.8280 \\
\hline Denmark & 0.8481 & 0.9617 & 0.7862 & 0.8503 & 0.5125 & 0.7917 \\
\hline Great Britain & 0.8561 & 0.8508 & 0.7761 & 0.8742 & 0.5104 & 0.7735 \\
\hline \multicolumn{7}{|c|}{ Actively developing } \\
\hline Norway & 0.6248 & 0.8410 & 0.5922 & 0.8914 & 0.5804 & 0.7059 \\
\hline France & 0.4651 & 0.5799 & 0,5450 & 0.8537 & 0.6110 & 0.6109 \\
\hline Germany & 0.3985 & 0.7804 & 0.6219 & 0.7551 & 0.5346 & 0.6181 \\
\hline Italy & 0.5648 & 0.5814 & 0.6770 & 0.7457 & 0.3908 & 0.5919 \\
\hline $\begin{array}{l}\text { Czech } \\
\text { Republic }\end{array}$ & 0.4139 & 0.7261 & 0.6820 & 0.7868 & 0.3110 & 0.5839 \\
\hline Estonia & 0.3430 & 0.5478 & 0.6103 & 0.6330 & 0.6037 & 0.5475 \\
\hline \multicolumn{7}{|c|}{ Average level of development } \\
\hline Hungary & 0.2716 & 0.6430 & 0.5701 & 0.7753 & 0.4175 & 0.5355 \\
\hline Poland & 0.3581 & 0.5321 & 0.6215 & 0.7140 & 0.3253 & 0.5102 \\
\hline Bulgaria & 0.2710 & 0.4739 & 0.0554 & 0.6640 & 0.5018 & 0.3932 \\
\hline Russia & 0.3570 & 0.2567 & 0.5028 & 0.3675 & 0.4091 & 0.3786 \\
\hline \multicolumn{7}{|c|}{ Low level of development } \\
\hline Uruguay & 0.4081 & 0.1749 & 0.5205 & 0.0 & 0.0 & 0.2207 \\
\hline
\end{tabular}

a. Source: Calculated by the author

The data in Table III shows that the development of the digital economy in Russia is much lower than in the EU countries and is only slightly ahead of Uruguay, whose digital economy is the weakest in terms of its level of development.

Thus, the results of the study show that despite the leading position of some European countries not only in comparison with Russia, but also on a global scale, the digitalization of the economy and society is happening at a comparable pace. It should also be noted that in the case of Russia, this development is of great importance from the point of view of increasing the country's competitiveness in the world market and increasing the development of public thought, the level and quality of life.

\section{DISCUSSION}

According to experts, today the backlog of Russia from developed countries in terms of the level of development of the digital economy is 5-8 years. It should be noted that most of the domestic digital economy (\$63 billion) falls to the sphere of consumption (online commerce, online services) [8].

In our opinion, such a low rating for the above indicators, which determine the level of development of the digital economy in the country, is caused by the following factors:

- the lack of appropriate, necessary infrastructure for the release of unique Russian information products both to the world market and for introduction into the domestic market of the country; 
- underestimation and fear of Russian businessmen of the possibilities of the digital economy and its impact on the efficiency, productivity and growth potential of the business, as well as increasing its competitiveness in the market;

- nowadays, there is an acute problem of legal regulation and ensuring data protection, which is crucial in the development and implementation of IT. The collection of data and its use by third parties raises many controversial issues regarding the protection of competition and intellectual property rights.

To overcome these problems, the author proposes the following measures:

- an important aspect in the formation and implementation of the digital economy is the implementation of state regional policy, which should be aimed primarily at solving the following problems: increasing the investment attractiveness of the regions and innovative activity in them; development of industrial and social infrastructure; minimization of regional imbalances in the sphere of socio-economic development of regions; rational use of human potential;

- creation of conditions for teaching and further training of specialists in the field of digital economy and innovative technologies at the state level. So, in our opinion, an interesting proposal is the creation of scientific, industrial and educational complexes (consortia) as mechanisms for building platforms new business units, participants in the digital economy, which will increase the level of digitalization of the country's economy and society;

- formation of a stably functioning system of international cooperation in the field of innovative scientific and technological development of countries, including in the field of digital economy;

- creation and widespread introduction of a system of incentives for the use of digital and innovative technologies of entrepreneurs conducting small and medium-sized businesses in their economic activities through tax incentives, government orders and other events. At the same time, the model of building effective interaction between the subjects of the "business - power" system is inalienable and important;

- in the context of the development of digital economy, it is necessary to ensure a legal regime within which innovations, on the one hand, will develop freely, and, on the other hand, potential risks associated with unfair competition and protection of intellectual property rights will be averted.

\section{CONCLUSIONS}

The pace and scale of the transition of the Russian economy to a digital one determine Russia's place in the world economy. A large role in the management of digitalization at the national level is assigned to the state, which should take specific measures to organize the processes of digitalization, legal regulation, financing and effective management

An analysis of the current state of digitalization of the Russian economy and society has identified problem issues that require close attention. It also confirmed that in order to obtain positive results from the impact of the global digitalization trend in Russia, it is necessary:

- to have such management of all aspects of economic and social life, which would ensure the fulfillment of the requirements of digitalization as a global trend for the effective development of the economy and society. Only in this case, digitalization will lead to the expected positive results;

- to create opportunities for implementing the prerequisites for digitalization as favorable conditions conducive to its positive impact on the economic and social life of the country.

Despite the fact that the introduction of digital technologies in many countries, including Russia, over the past decades has acquired the status of a "traditional" area of development both at the state and corporate levels, the current stage characterized by the formation of the so-called digital economy gives rise to a fundamental new technological, organizational and management challenges. At the same time, operational definitions of new key concepts have not yet been formed, not to mention a full-fledged regulatory framework and regulatory mechanisms, which hinders the development of the digital economy and the possibility of realizing the positive effects associated with it.

\section{References}

[1] A.Yu. Tabunshchikov, "Digitalization of the economy - a global trend", Energy Saving, no. 7, pp. 4-10, 2018.

[2] "What is the digital economy? Trends, competencies, measurement", [HSE University report to the XX April International Scientific Conference on the Problems of Economic and Social Development]. Moscow: HSE Publ. House, 2019, p. 85.

[3] Digital Russia: a new reality, McKinsey report. Moscow: Digitaal/McKinsey, 2017, pp. 7-14.

[4] V.I. Talantsev, A.K. Ravnyansky, "Digital economy and its role in the development of small and medium innovative entrepreneurship in Russia", Econ. of entrepreneurship, no. 2, pp. 80-86, 2018.

[5] A.V. Babkin, D.D. Burkaltseva, D.G. Kosten, Yu.N. Vorobyov, "Formation of the digital economy in Russia: essence, features, technical normalization, development problems", St. Petersburg Polytechnic Univer. J. Econ. sci., vol. 10, no. 3, pp. 9-25, 2017.

[6] Indicators of the digital economy: 2019, Statistical compilation. National Research University "Higher School of Economics", Moscow: NRU HSE, 2019, p. 248.

[7] V.G. Khalin, G.V. Chernova, "Digitalization and its impact on the Russian economy and society: advantages, challenges, threats and risks", Manag. consulting, no. 10, pp. 46-63, 2018.

[8] Platform Economy: Technology-driven business model innovation from the outside in, Dublin: Accenture, 2016, p. 15.

[9] J.A. Mohd, S.I. Jasni Zain, A.N. Nur Asyikin, DESA: Growing the Digital Economy from a National Perspective, Malaysia, pp. 1-10, 2016

[10] R. Asen, B. Blechschmidt, "Making Digital, Real and Rewarding", Cognizanti, vol. 9 , no. 1, pp. 2-13, 2016. 
[11] M. Bahl, The work ahead: The future of businesses and jobs in Asia pacific's digital economy. Chennai: Cognizant, 2016, p. 32.

[12] The Digital Economy, Second report of session 2016-17. London: British Computer Society. 2016, p. 37.

[13] C. Dahlman, S. Mealy, M. Wermelinger, Harnessing the digital economy for developing countries. Paris: OECD, 2016, p. 80.

[14] D. Dean et al., The internet economy in the G-20, Report.Boston: Boston Consulting Group, 2012, p. 57.
[15] Digital middle east: transforming the region into a leading digital economy. New York: McKinsey \& Company, 2016, p. 66.

[16] Challenges for competition policy in a digitalised economy. European Parliament. Brussels, 2015, p. 84.

[17] G20 digital economy development and cooperation initiative. China, 2016, pp. 1-8.

[18] G. Petropoulos, "An economic review of the collaborative economy", Policy contribution, no. 5, pp. 1-17, 2017. 